\title{
Coastal, Ocean and Marine Engineering Graduate Education: A 2012 Health Assessment
}

\section{Dr. Robert W. Whalin PE, Jackson State University}

Robert W. Whalin, Ph.D., PE is Professor of Civil Engineering, and Director, Center of Excellence for Natural Disasters, Coastal Infrastructure and Emergency Management, College of Science, Engineering \& Technology, Jackson State University. He is Director Emeritus of the Engineer Research and Development Center, Vicksburg, MS. He received his Ph.D. in Oceanography from Texas A\&M University in 1971 and is a Registered Professional Engineer. Dr. Whalin was Director of Army Research Laboratory (19982003; Adelphi, Md.), and Technical Director /Director of Waterways Experiment Station (1985-1998; Vicksburg, Miss.). He has authored/co-authored over a hundred technical papers and reports during his career in private industry, government and academia. His current research interests are nearshore wave transformations, coastal structures, tsunami inundation, hurricane surges, high performance computing, and engineering education.

\section{Ms. Qing Pang, Jackson State University}

Ms Qing Pang is Research Associate in the Department of Computer Engineering, School of Engineering, College of Science, Engineering \& Technology, Jackson State University. She earned her M.S. in Electrical and Computer Engineering from Georgia Institute of Technology in 2000. She worked for several private companies before joining Jackson State University in 2007. Her current research interests are robotics, wireless sensor networks, signal processing, embedded software and engineering education. 


\title{
Coastal, Ocean and Marine Engineering Graduate Education: A 2012 Health Assessment of USA Programs
}

\begin{abstract}
Many practitioners (academic, government, industry) of coastal, ocean and marine engineering in the USA have the perception that this once remarkably prolific set of graduate engineering programs are collectively in an overall state of decline. Typical comments revolve around the perceived diminishing number and stature of university and US Government research publications, experimental facilities and field measurement programs. The perception that full scale field measurements are both less robust and more scarce than in decades past seems to be widespread. In the middle of the twentieth century, the largest scale coastal, ocean and marine engineering laboratory facilities were in the United States. The largest scale such facilities are in foreign countries at the present time. Experimental modeling of US Navy ships in the presence of storm waves is performed in a foreign laboratory. With the explosion of high end supercomputer facilities, atmospheric, coastal and ocean modeling made great strides and computational fluid dynamics (CFD) came into its own and took a seat at the table with the most advanced experimental research facilities and field measurement programs during the last four decades. Government laboratories aggressively took advantage of CFD assets with the Army Corps of Engineers, National Oceanographic and Atmospheric Administration and Office of Naval Research leading the way. European and Japanese laboratories were making CFD advances simultaneously. A clear CFD leader has not (nor is expected to) emerged, but CFD is in its heyday and competes with the most advanced experimental research, the most innovative field measurements, and the highest end theoretical work for research advances in coastal, ocean and marine engineering.

This paper explores the ebb and flow of coastal, ocean and marine engineering research and academic programs demonstrating a decline in the robustness of US research relative to that in other countries. A qualitative case is made for a robust long term US investment in graduate academic research in coastal, ocean and marine engineering accompanied by a renewed national investment in large scale experimental facilities and full scale research programs in the field. Recommendations are made for the way forward to revive this struggling profession which, if implemented, should produce economic dividends for the USA far in excess of the investment and is hypothesized to contribute significantly to national economic security and national defense. We would like for this paper to stimulate a national dialogue leading to a dynamic revival of Coastal, Ocean and Marine Engineering research and graduate education in the United States.
\end{abstract}

\section{Background}

A compelling argument can be made that the coastal engineering profession was born with legislation by the U.S. Congress that established the Beach Erosion Board and subsequently the Coastal Engineering Research Board for the purpose of advising the Chief of Engineers on the direction that coastal engineering research should take to enable the nation to solve pressing beach erosion challenges. For over 30 years from the 1930's, to the 1960's, the Beach Erosion Board and the Coastal Engineering Research Center (located at Dale Carlia Reservoir outside 
Washington, DC and subsequently moved to Ft. Belvoir, VA) were the unchallenged leaders for funding academic coastal engineering research in the USA.

During and after World War II, the Navy and Marine Corps began funding coastal, ocean and marine engineering related research. The Office of Naval Research and Navy laboratories were funded robustly. These included the U.S. Navy David Taylor Model Basin (DTMB) that thrived with the world's largest towing tanks and world renowned ship resistance experimental investigations. The Naval Research Laboratory, Naval Oceanographic Office, Naval Civil Engineering Laboratory, Fleet Numerical Weather Central, the Naval Ocean Research and Development Activity and the Naval Coastal Systems Laboratory all helped contribute to supporting academic education and research through the early cold war era into the early 1970's. Simultaneously, related programs in Oceanography and Naval Architecture were robustly funded by National Science Foundation, and the National Oceanographic and Atmospheric Administration (after its formation in 1970) and the NOAA National Data Buoy Center, National Weather Service, National Hurricane Center.

Through the 1950's and early sixties, the principle coastal and ocean engineering academic programs were University of California at Berkeley, California Institute of Technology, Massachusetts Institute of Technology and University of Florida. A highly robust Oceanography Program at Texas A\&M University spawned a thriving Ocean Engineering graduate program and subsequently a large undergraduate Ocean Engineering program. The robust graduate oceanography programs at Scripps Institution of Oceanography spawned research in coastal sediment transport and nearshore wave transformations. The U.S. Naval Postgraduate School had some highly renowned professors who contributed substantially to research advances in coastal and ocean engineering. The University of Rhode Island, University of Delaware and University of Miami developed strong and well recognized ocean and/or coastal engineering programs. Many university graduate programs in coastal and ocean engineering thrived during the 1960's and early 1970's with one or two well known professors who collectively produced a steady stream of MS and $\mathrm{PhD}$ graduates. These included Stanford University, University of Washington, University of Oregon, Oregon State University, U.C. Davis, University of California at San Diego, Louisiana State University, University of Texas, University of Houston, University of Wyoming, Southwest Louisiana University, University of New Orleans, University of South Alabama, Florida Atlantic University, Florida Institute of Technology, Old Dominion, Clemson, University of South Carolina, North Carolina State University, Duke, University of Virginia, Johns Hopkins University, Cornell, University of New York at Buffalo, New York University, University of New Hampshire, Harvard, University of Michigan, Purdue, University of Chicago, University of Minnesota, and University of Hawaii. We apologize if we have inadvertently omitted some eminent programs.

\section{Laboratory Facilities}

Coastal/ocean engineering laboratory facilities reigned supreme in the United States through the 1950's. The Beach Erosion Board had the largest wave tank in the world (approximately $600 \mathrm{ft}$. long and 20 wide and 20ft deep) and large outdoor sand transport basins. The Waterways Experiment Station had pioneering mid-size wave flumes where experiments were performed for the expedient breakwaters used in the Normandy Invasion during World War II. These facilities were modernized in late 1960's through the 1970's with 3-dimensional experimental basins spectral wave generators and mid-sized wave flumes. In the late 1970's 
WES added a shallow-water movable directional spectral wave generator to a large wave basin and all other wave generators were upgraded to produce spectral waves. This facility contained the first relatively large (and long-120') shallow-water directional spectral wave generator. University of California at Berkeley had extensive coastal model facilities and prolific research results emanated from Berkeley in the 50's, 60's and 70's involving sediment transport and port and harbor research challenges. The first Oceanographical Engineering text and reference book was authored by Robert L. Weigel, UC Berkeley in 1964.[1] MIT had preeminent hydrodynamic laboratory facilities in the 50's and 60's where Profs. Ippen and Eagleson produced numerous PhD's who were instrumental in leading national coastal and ocean engineering research and education for the next three or four decades. The classic text Estuary and Coastline Hydrodynamics, published in 1966 was edited by Arthur T. Ippen, Ford Professor of Engineering, Director of Hydrodynamics Laboratory, Department of Civil Engineering, MIT.[2]

\section{Publications in Proceedings of the International Conference on Coastal Engineering (ICCE)}

The authors hypothesized that an evaluation of publications in ICCE Proceedings might shed light on USA research leadership in the coastal and ocean engineering professions. We analyzed the nation represented by the first authors of all ICCE publications that were from conferences held in the USA. The rationale for this selection was that attendance and publication would always be biased to larger numbers of publications by authors from the country where the conference was held. A total of thirty-three ICCE conferences have been held through 2012; six have been held in the USA.[Reference 3,4,5,6,7,8] The cities of the six USA conferences were (Gainesville, FL; Washington DC; Honolulu, HI; Houston, TX; Orlando, FL and San Diego, CA). Table 1 and Figure 1 display results from this analysis which show a remarkably strong decline in the percent of publications by first authors from the USA. The number of publications and the year of the Proceedings are displayed in Table 1 for this half century time period.

\begin{tabular}{|c|c|c|c|c|}
\hline $\begin{array}{c}\text { Year of } \\
\text { Proceedings }\end{array}$ & $\begin{array}{c}\text { Number of } \\
\text { U.S. Authors }\end{array}$ & $\begin{array}{c}\text { Number of } \\
\text { Foreign } \\
\text { Authors }\end{array}$ & $\begin{array}{c}\text { Total } \\
\text { Number of } \\
\text { Papers }\end{array}$ & $\begin{array}{c}\text { \% of papers } \\
\text { by U.S. } \\
\text { Authors }\end{array}$ \\
\hline 1957 & 24 & 30 & 54 & $56 \%$ \\
\hline 1970 & 70 & 68 & 138 & $51 \%$ \\
\hline 1976 & 101 & 105 & 206 & $49 \%$ \\
\hline 1984 & 90 & 128 & 218 & $41 \%$ \\
\hline 1996 & 110 & 265 & 375 & $29 \%$ \\
\hline 2006 & 131 & 314 & 445 & $29 \%$ \\
\hline
\end{tabular}

Table 1. Number and Percent of ICCE Proceedings Papers by USA Authors 


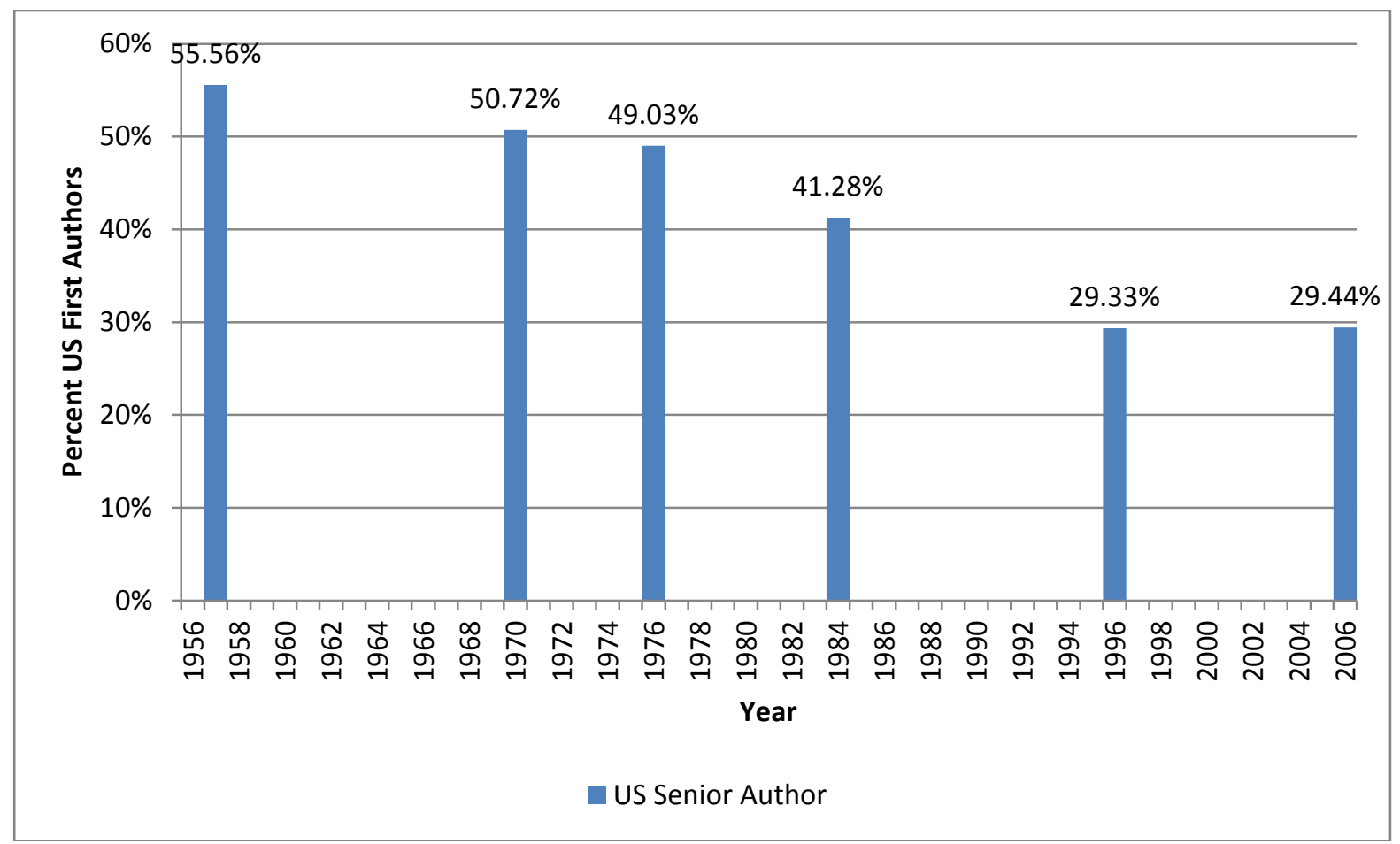

Figure 1. Percent of ICCE Proceedings Papers by USA Authors

The ICCE is arguably the most prestigious Coastal Engineering Conference worldwide and is sponsored by the American Society of Civil Engineers (ASCE) when held in the USA and by ASCE and the other nations counterpart professional organization when held outside the USA. Data displayed in Figure 1 seem to unequivocally indicate that the USA is declining in worldwide research leadership in coastal and ocean engineering. The decline results from an explosion of research in other nations relative to a more stable amount of USA research.

\section{Academic Degree Programs in Coastal, Ocean and Marine Engineering}

The degree productivity of academia in coastal, ocean and marine engineering was analyzed using data tabulated in the ASEE Profiles of Engineering Colleges and Universities [9] which is the most comprehensive source for data on degrees awarded and student enrollment in ABET accredited Engineering and Engineering Technology programs in the USA. These data are only detailed enough to display results from 2005 through 2011. Data for 2012 will be finalized shortly and added to the compilation when available. Table2 lists the 14 universities with degree programs in coastal and/or ocean engineering. Seven have BS degree programs in Ocean Engineering; thirteen universities have $17 \mathrm{MS}$ and ME degree programs (9 MS and $5 \mathrm{ME}$ in Ocean Engineering, one MS and one ME Coastal and Ocean Engineering, and one MS in Ocean and Resources Engineering); and 11 universities have $13 \mathrm{PhD}$, ScD and D Engr. programs (9 PhD, one ScD and one D.E. in Ocean Engineering, one PhD in Ocean and Resource Engineering and one PhD in Coastal and Ocean Engineering). 


\begin{tabular}{|c|c|c|c|c|}
\hline & University & $\begin{array}{l}\text { Undergraduate } \\
\text { Programs }\end{array}$ & Master Programs & PhD Programs \\
\hline 1 & $\begin{array}{l}\text { Florida Atlantic } \\
\text { University }\end{array}$ & $\begin{array}{l}\text { Ocean Engineering } \\
\text { (B.S.) }\end{array}$ & $\begin{array}{l}\text { Ocean Engineering } \\
\text { (M.S.) }\end{array}$ & $\begin{array}{l}\text { Ocean Engineering } \\
\text { (Ph.D.) }\end{array}$ \\
\hline 2 & $\begin{array}{l}\text { Florida Institute of } \\
\text { Technology }\end{array}$ & $\begin{array}{l}\text { Ocean Engineering } \\
\text { (B.S.) }\end{array}$ & $\begin{array}{l}\text { Ocean Engineering } \\
\text { (M.S.) }\end{array}$ & $\begin{array}{l}\text { Ocean Engineering } \\
\text { (Ph.D) }\end{array}$ \\
\hline 3 & $\begin{array}{l}\text { Massachusetts } \\
\text { Institute of Tech. }\end{array}$ & $\begin{array}{l}\text { Ocean Engineering } \\
\text { (S.B.) }\end{array}$ & $\begin{array}{l}\text { Ocean Engineering } \\
\text { (S.M.) }\end{array}$ & $\begin{array}{l}\text { Ocean Engineering } \\
\text { (Ph.D., ScD) }\end{array}$ \\
\hline 4 & $\begin{array}{l}\text { Oregon State } \\
\text { University }\end{array}$ & & $\begin{array}{l}\text { Ocean Engineering } \\
\text { (M.E.) }\end{array}$ & \\
\hline 5 & $\begin{array}{l}\text { Stevens Institute of } \\
\text { Technology }\end{array}$ & & $\begin{array}{l}\text { Ocean Engineering } \\
\text { (M.E.) }\end{array}$ & $\begin{array}{l}\text { Ocean Engineering } \\
\text { (Ph.D.) }\end{array}$ \\
\hline 6 & $\begin{array}{l}\text { Texas A\&M } \\
\text { University }\end{array}$ & $\begin{array}{l}\text { Ocean Engineering } \\
\text { (B.S.) }\end{array}$ & $\begin{array}{l}\text { Ocean Engineering } \\
\text { (M.S., M.E.) }\end{array}$ & $\begin{array}{l}\text { Ocean Engineering } \\
\text { (Ph.D.) }\end{array}$ \\
\hline 7 & U.S. Naval Academy & $\begin{array}{l}\text { Ocean Engineering } \\
\text { (B.S.) }\end{array}$ & & \\
\hline 8 & $\begin{array}{l}\text { University of } \\
\text { California-Berkeley }\end{array}$ & & $\begin{array}{l}\text { Ocean Engineering } \\
\text { (M.S., M.E.) }\end{array}$ & $\begin{array}{l}\text { Ocean Engineering } \\
\text { (PhD., D.E.) }\end{array}$ \\
\hline 9 & $\begin{array}{l}\text { University of } \\
\text { Delaware }\end{array}$ & & $\begin{array}{l}\text { Ocean Engineering } \\
\text { (MS) }\end{array}$ & $\begin{array}{l}\text { Ocean Engineering } \\
\text { (PhD) }\end{array}$ \\
\hline 10 & $\begin{array}{l}\text { University of Hawaii } \\
\text { at Manoa }\end{array}$ & & $\begin{array}{l}\text { Ocean \& Resources } \\
\text { Engineering (M.S.) }\end{array}$ & $\begin{array}{l}\text { Ocean and } \\
\text { Resources } \\
\text { Engineering (Ph.D.) }\end{array}$ \\
\hline 11 & $\begin{array}{l}\text { University of New } \\
\text { Hampshire }\end{array}$ & & $\begin{array}{l}\text { Ocean Engineering } \\
\text { (M.S.) }\end{array}$ & $\begin{array}{l}\text { Ph.D. in Ocean } \\
\text { Engineering }\end{array}$ \\
\hline 12 & $\begin{array}{l}\text { University of Rhode } \\
\text { Island }\end{array}$ & $\begin{array}{l}\text { Ocean Engineering } \\
\text { (B.S.) }\end{array}$ & $\begin{array}{l}\text { Ocean Engineering } \\
\text { (M.S.) }\end{array}$ & $\begin{array}{l}\text { Ocean Engineering } \\
\text { (Ph.D.) }\end{array}$ \\
\hline 13 & $\begin{array}{l}\text { Virginia Polytechnic } \\
\text { Institute \& State } \\
\text { Univ. }\end{array}$ & $\begin{array}{l}\text { Ocean Engineering } \\
\text { (B.S.) }\end{array}$ & $\begin{array}{l}\text { Ocean Engineering } \\
\text { (M.S., M.E.) }\end{array}$ & \\
\hline 14 & University of Florida & & $\begin{array}{l}\text { Coastal \& Ocean } \\
\text { Engineering (M.S., } \\
\text { M.E.) }\end{array}$ & $\begin{array}{l}\text { Coastal \& Ocean } \\
\text { Engineering (Ph.D.) }\end{array}$ \\
\hline
\end{tabular}

Table 2. University Degree Programs in Coastal or Ocean Engineering

Enrollment data and degree data from these 14 universities are shown in Figures 2 and 3. These data (Figure 2 and Figure 3 from 2005 thru 2011) do not seem to support the perception of a decline in the influence of USA coastal and ocean engineering leadership. However, these data cover a relatively small period of time insufficient to extrapolate to expect future research productivity from the number of graduates denoted. If analogous data were available, from 1950 forward, the results might be more revealing. 


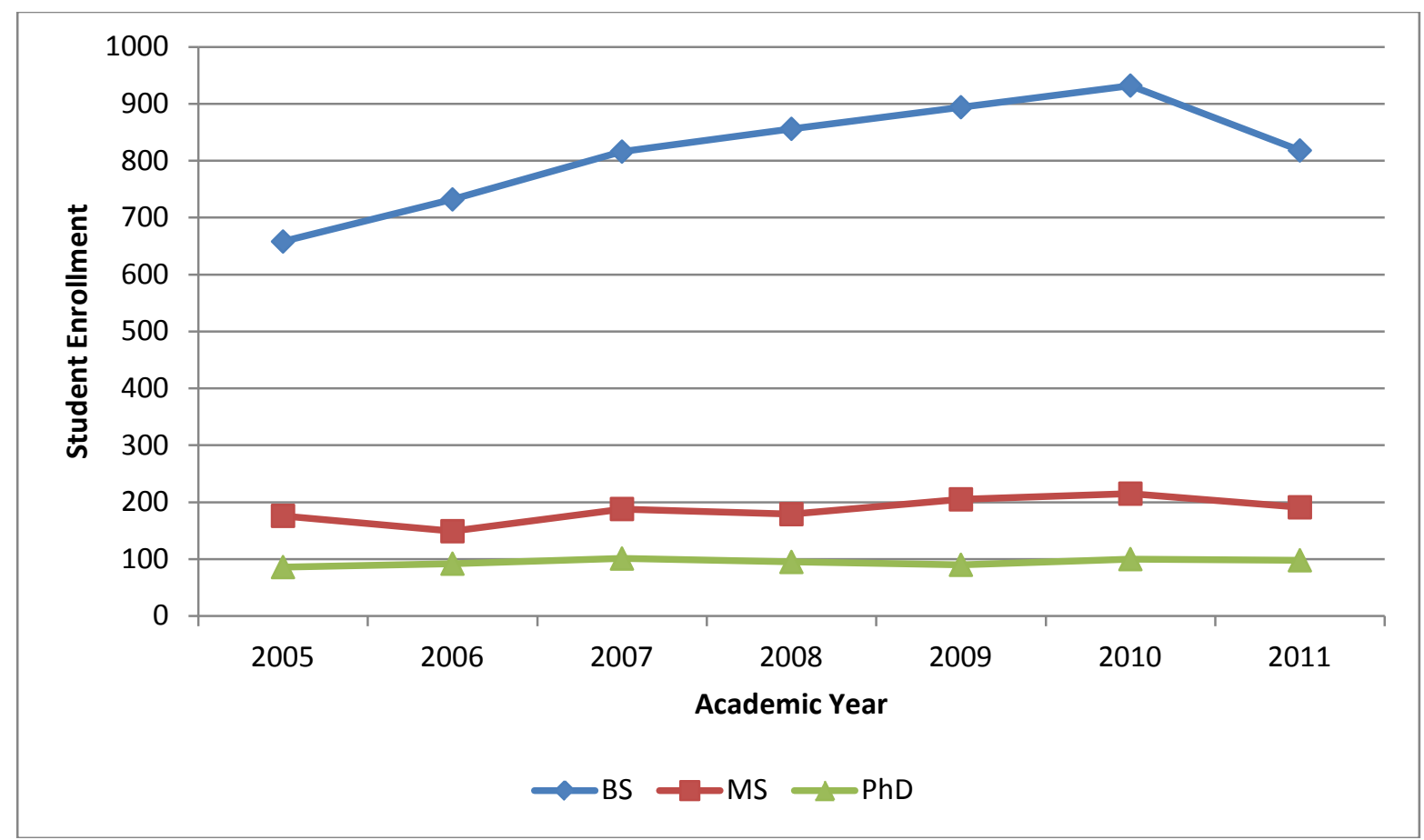

Figure 2. Ocean and Coastal Engineering Enrollment Data

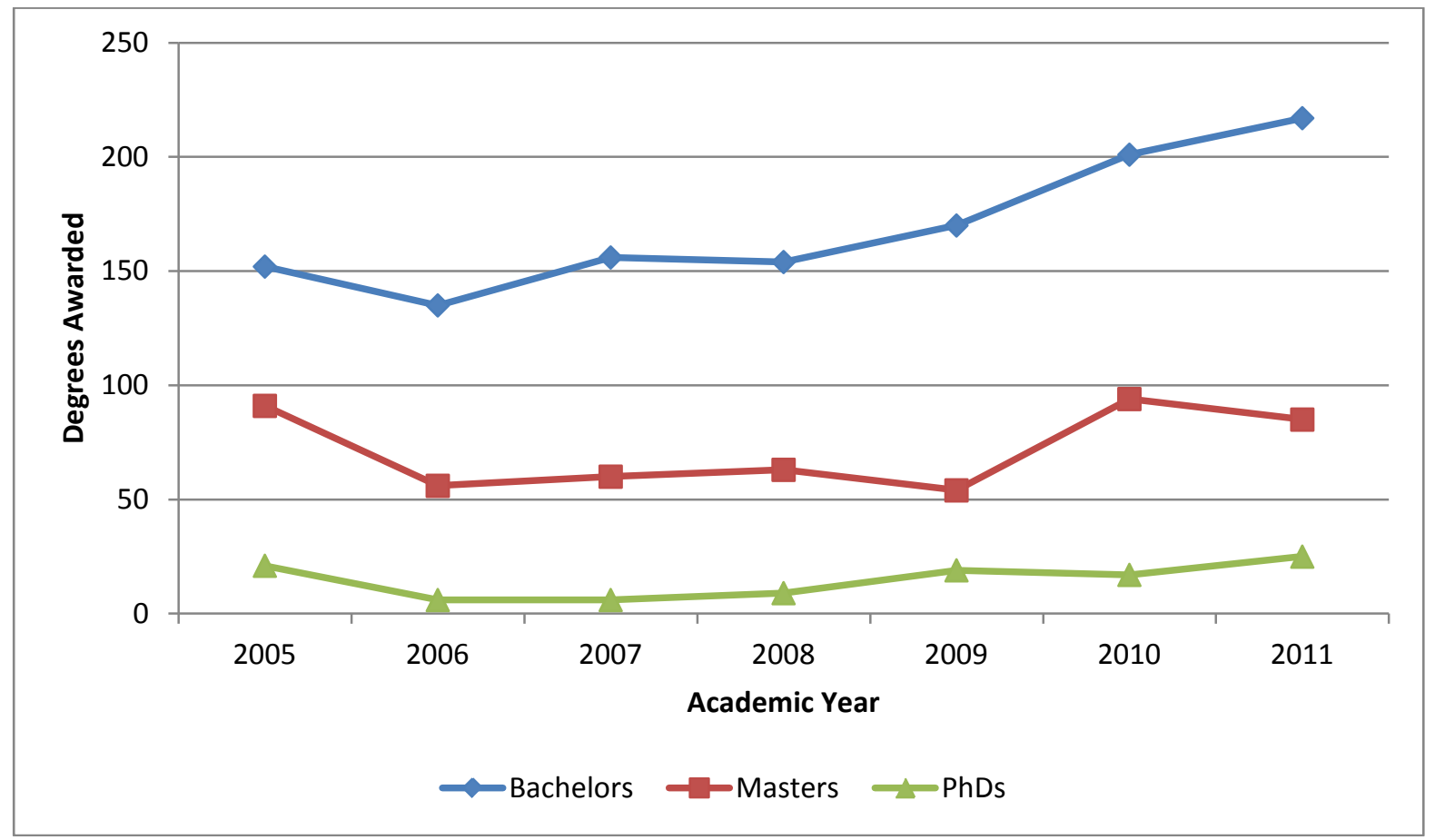

Figure 3. Ocean and Coastal Engineering Degrees Awarded

Analogous data are in Table 3 and Figures 4 and 5 for Marine_Engineering and Naval Architecture programs. These Marine Engineering programs are contained in nine universities 
(9 with BS programs, 4 with MS programs and two with PhD programs). Figures 4 and 5 show the degrees granted and enrollment data. Of the 9 universities with 13 BS level programs, 3 are in Marine Engineering; 3 are in Marine Systems Engineering; 4 are in Naval Architecture and Marine Engineering, 1 is in Marine Engineering and Shipyard Management, 1 is in Atmospheric, Ocean and Space Science and 1 is in Earth System Science and Engineering. Four universities have 8 degree programs at the MS level (6 in Naval Architecture and Marine Engineering, I in Marine Engineering and Marine Design, and one in Marine Engineering). Two universities have PhD programs, one in Naval Architecture and Marine Engineering and the other in Naval Architecture, Marine Engineering and Applied Science.

\begin{tabular}{|c|c|c|c|c|}
\hline & University & $\begin{array}{l}\text { Undergraduate } \\
\text { Programs }\end{array}$ & Masters Programs & PhD Programs \\
\hline 1 & $\begin{array}{l}\text { Maine Maritime } \\
\text { Academy }\end{array}$ & $\begin{array}{l}\text { Marine Systems } \\
\text { Engineering (B.S.) }\end{array}$ & & \\
\hline 2 & $\begin{array}{l}\text { Massachusetts } \\
\text { Institute of Tech. }\end{array}$ & $\begin{array}{l}\text { Marine Engineering } \\
\text { (B.S.) }\end{array}$ & $\begin{array}{l}\text { Naval Architecture \& } \\
\text { Marine Engr. (S.M.) }\end{array}$ & \\
\hline 3 & $\begin{array}{l}\text { State University of } \\
\text { NY Maritime } \\
\text { College }\end{array}$ & $\begin{array}{l}\text { Marine Systems } \\
\text { Engineering (B.S.) }\end{array}$ & & \\
\hline 4 & $\begin{array}{l}\text { Texas A\&M } \\
\text { University- } \\
\text { Galveston }\end{array}$ & $\begin{array}{l}\text { Marine Engineering } \\
\text { (B.S.) }\end{array}$ & & \\
\hline 5 & $\begin{array}{l}\text { U.S. Coast Guard } \\
\text { Academy }\end{array}$ & $\begin{array}{l}\text { Naval Architecture \& } \\
\text { Marine Engr. (B.S.) }\end{array}$ & & \\
\hline \multirow[t]{3}{*}{6} & $\begin{array}{l}\text { U.S. Merchant } \\
\text { Marine Academy }\end{array}$ & $\begin{array}{l}\text { Marine Engr. and } \\
\text { Shipyard Mgmt. (B.S.) }\end{array}$ & & \\
\hline & & $\begin{array}{l}\text { Marine Engineering } \\
\text { (B.S.) }\end{array}$ & $\begin{array}{l}\text { Marine Engineering } \\
\text { (MMarE) }\end{array}$ & \\
\hline & & $\begin{array}{l}\text { Marine Engineering } \\
\text { Systems (B.S.) }\end{array}$ & & \\
\hline \multirow[t]{3}{*}{7} & $\begin{array}{l}\text { University of } \\
\text { Michigan }\end{array}$ & & $\begin{array}{l}\text { Concurrent Marine } \\
\text { Design (M.E.) }\end{array}$ & \\
\hline & & $\begin{array}{l}\text { Atmospheric, Oceanic } \\
\text { \& Space Science (B.S.) } \\
\text { Earth Systems Science } \\
\text { \& Engr. (B.S.E.) }\end{array}$ & $\begin{array}{l}\text { Naval Arch. and } \\
\text { Marine Engineering } \\
\text { (M.S.E./M.B.A.) }\end{array}$ & $\begin{array}{l}\text { Naval Arch. and } \\
\text { Marine Engineering } \\
\text { (Ph.D.) }\end{array}$ \\
\hline & & $\begin{array}{l}\text { Naval Architecture \& } \\
\text { Marine Engineering } \\
\text { (B.S.E.) }\end{array}$ & $\begin{array}{l}\text { Naval Architecture \& } \\
\text { Marine Engineering } \\
\text { (M.S., M.S.E.) }\end{array}$ & \\
\hline 8 & $\begin{array}{l}\text { University of New } \\
\text { Orleans }\end{array}$ & $\begin{array}{l}\text { Naval Architecture \& } \\
\text { Marine Engr. (B.S.) }\end{array}$ & $\begin{array}{l}\text { Engineering (M.S.) - } \\
\text { Naval \& Marine }\end{array}$ & $\begin{array}{l}\text { Naval/Marine Engr. } \\
\text { \& Applied Sci. PhD }\end{array}$ \\
\hline 9 & Webb Institute & $\begin{array}{l}\text { Naval Architectural \& } \\
\text { Marine Engr. B.S.E. }\end{array}$ & & \\
\hline
\end{tabular}

Table 3. University Degree Programs in Marine Engineering 


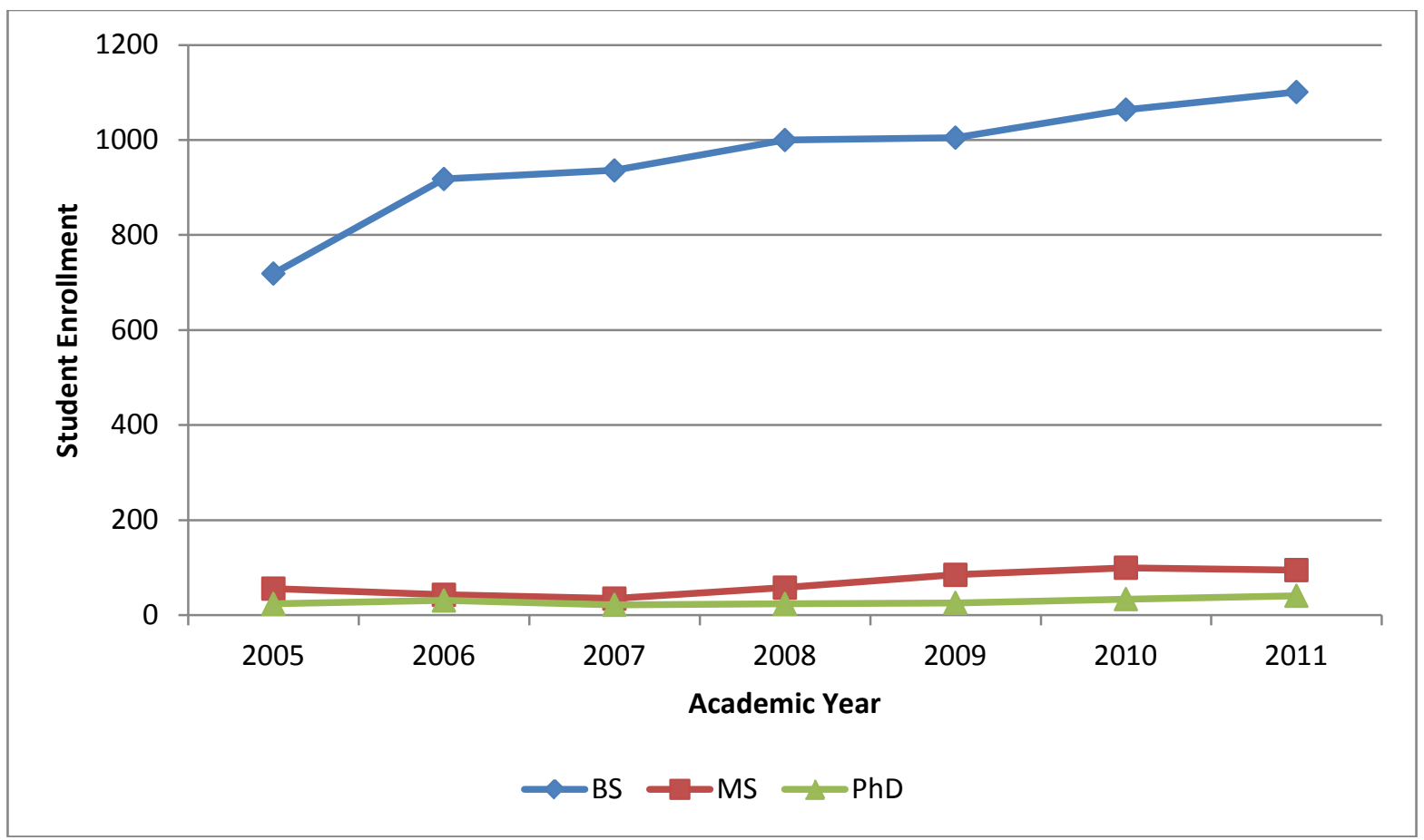

Figure 3. Marine Engineering Enrollment Data

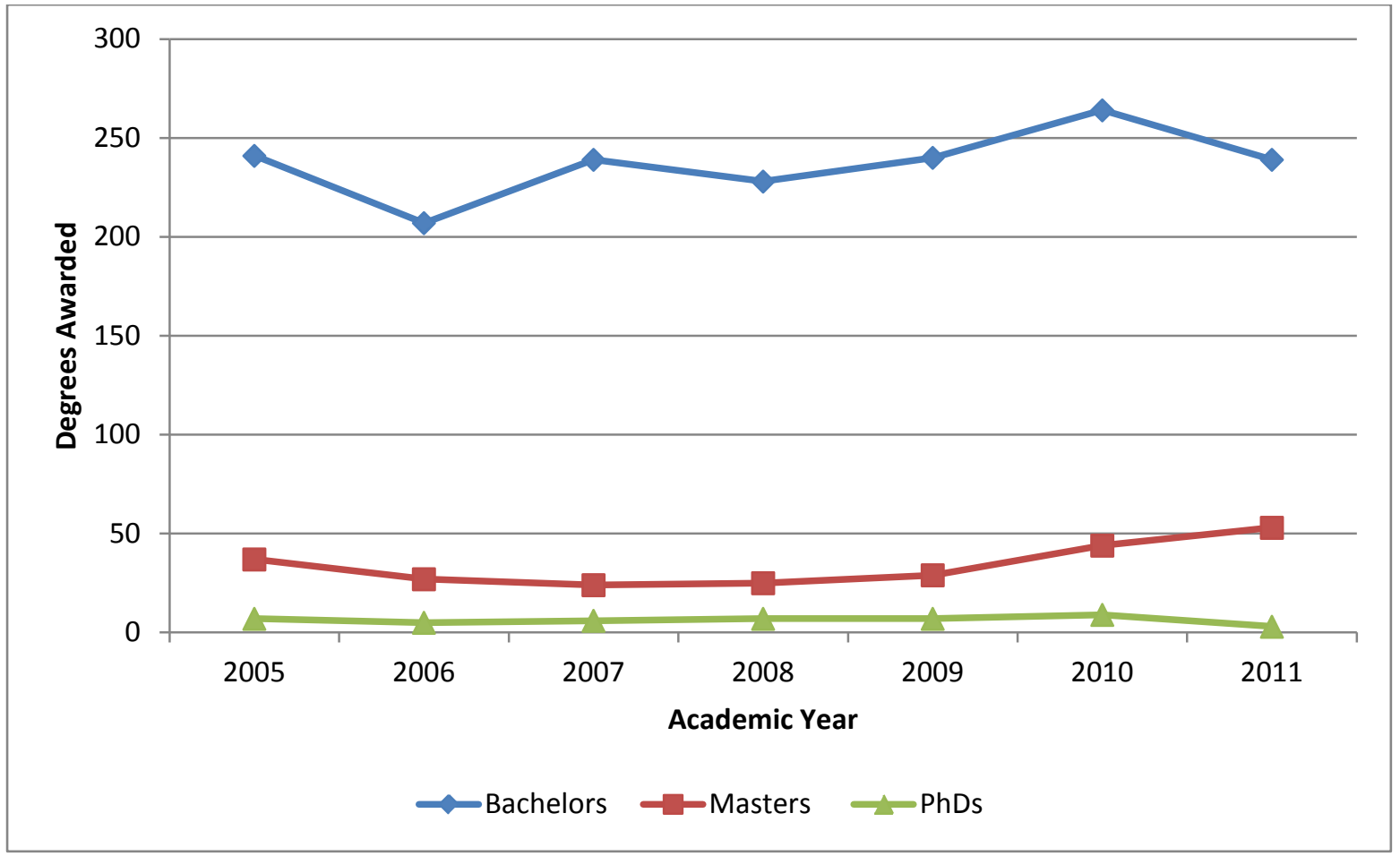

Figure 4. Marine Engineering Degrees Awarded

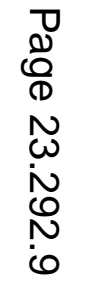




\section{Computational Coastal, Ocean and Marine Engineering}

Computational coastal and ocean engineering research and development started a steady acceleration in the mid to late 1960's and beyond that remains unabated today as computational assets become more powerful and access to visualization tools are commonplace. Coastal and ocean engineering research and education inevitably became more and more computationally oriented and computational fluid dynamics was fueled by the very high end computational needs for rapid weather and wave forecasting and quantitative design data in the coastal, ocean and atmospheric science and engineering fields. As the Cold War raged in the late 1940's, 1950's and 1960's the Los Alamos National Laboratory, Livermore National Laboratory and Oak Ridge National Laboratory continuously kept their scientific and engineering computational assets at the cutting edge. This spilled over to some segments of coastal and ocean engineering research and development including research on explosion generated water waves and tsunami research. The U.S. Navy's Fleet Numerical Weather Central implemented daily computational wave forecasts for the fleet. NCAR (National Center for Atmospheric Research) provided advanced computational assets to NOAA researchers. NOAA founded the U.S. Tsunami Early Warning Center using a combination of seismograph measurements, tide gauge measurements and computations of the arrival times and elevations of tsunamis that emanated throughout "ring of fire” around the pacific basin. World ocean weather forecasts, wave forecasts, ocean circulation, oil spill forecasts and forecasts of fish and shellfish resources have an insatiable appetite for more and faster computational capability. In my short lifetime, computational assets have grown from flops to kiloflops, to megaflops, to gigaflops, to terraflops to petaflops with no end in sight. Our National Science Foundation, Defense Advanced Research Projects Agency and Department of Energy have been instrumental in keeping overall U.S. computational science and engineering assets at the cutting edge. The National Hurricane Center (NHC) and Federal Emergency Management Agency (FEMA) performed in a highly effective manner during the 2012 Hurricane season with their forecasts, warnings and responses to Hurricane Issac and Hurricane Sandy. Computational assets of NOAA coupled with critical satellite data enabled a commendable level of hurricane forecast reliability. The US Army Corps of Engineers (during the 1970's) embraced use of the computational approach to develop design wave information (directional spectral wave statistics) for all US coastlines (including the Great Lakes, Alaska, Hawaii and U.S. territories) and they routinely update (about every 10 years) and extend the directional spectral design wave statistics which provides more and more reliability in extremal design wave statistics. The quantification of ocean warming on extremal directional spectral wave statistics must be accounted for separately.

All universities have computational assets (to one degree or another) available to their coastal, ocean and marine engineering faculty. US Government DOD laboratories have the highest end (hundreds of teraflops) computational assets available to government researchers

and, when authorized, their academic contractors. These high end resources are located at the Engineer Research and Development Center, Naval Oceanographic Office, Army Research Laboratory and Air Force Research Laboratory. NOAA has high end computational assets for its government and academic researchers at NCAR. 


\section{Laboratory Facilities}

The only large scale, coastal/ocean engineering experimental facility in the US constructed in the past decade is a tsunami basin at Oregon State University. The U.S. Navy exports its experimental studies of ship response to ocean waves to the Norwegian Hydraulic Laboratory in Trondheim, Norway (for the last three decades) where they have the world's first (and largest scale) deep water directional spectral wave basin. It was constructed, largely due to the foresight of Dr. Per Bruun, a visionary Norwegian coastal/ocean engineer (who was in the USA for a number of years). The largest scale wave flume in the world is at the Hydraulic Laboratory in Hannover, Germany. This wave flume became operational in 1983. The Delft Hydraulics Laboratory in The Netherlands has extensive large scale experimental coastal engineering facilities. Other European laboratories in Spain, Portugal, Italy, United Kingdom, Denmark and Sweden have mid-sized wave flumes and wave basins. Principle large scale academic coastal and ocean engineering experimental facilities in the USA are located at Oregon State University, Texas A\&M University, University of Florida (major facility partially closed), and University of Delaware. Many other universities have research facilities at a smaller scale that are excellent for education and smaller scale research.

Government coastal and ocean engineering facilities are primarily located at the Coastal Engineering Research Center, in the Coastal and Hydraulics Laboratory of the U.S. Army Engineer Research and Development Center (ERDC) in Vicksburg, MS. All these facilities would be classified as mid-sized wave flumes and large, intermediate to shallow water, wave basins with directional spectral or spectral wave generators. Complementary Ice Engineering experimental facilities are located at the ERDC Cold Regions Research and Engineering Laboratory in Hanover, New Hampshire.

\section{Field Measurement Facilities}

The most extensive coastal/ocean engineering field measurement facility in the US is at Duck, North Carolina on the Outer Banks. The ERDC has a Field Research Facility on a mile of beachfront with a research pier extending to the 30ft water depth. This facility is hurricane proof and has been continually manned by about 10 coastal and ocean engineers and staff for over three decades. ERDC owns a 1 mile strip of the barrier island from the Atlantic Ocean to Currituck Sound. Periodic national/international experiments with a specific research theme have been held with researchers worldwide being invited to bring their instrumentation (about every two years for a long period of time). Continuous wave, current bathymetric and sediment transport measurements are collected and they constitute the most comprehensive quantitative long term (over 30 years) data base of its kind worldwide. The University of California at San Diego (Scripps Institution of Oceanography in La Jolla, CA) has a well known research pier from which many deep ocean and coastal oceanographic field experiments have been launched over the past six decades.

\section{Attempt to Quantify the National Priority of Coastal, Ocean and Marine Engineering Research}

It appears that a case can be made that U.S worldwide/leadership in Coastal, Ocean and Marine Engineering has been on a decline for several decades. The percent of ICCE papers by 
US first authors has declined from 56\% in 1957 to 29\% in 2006. Many consider this to be most prestigious publication venue in the coastal engineering profession. The US no longer has the major large scale facilities for coastal and ocean engineering experimental research as it did during the 1950's and 1960's. However, government and academic facilities are reasonably plentiful, are mid-scale and are somewhat unique at the intermediate and shallow water depth scales. The availability of high-end computational assets for cutting edge computational fluid dynamics research in coastal, ocean, and marine engineering in the US is one area where the US researchers appear to be leading or certainly co-leading the profession. The US Army ERDC Field Research Facility located on the outer banks of North Carolina represents a unique research facility world-wide for conducting pioneering full scale coastal engineering field measurement programs. The recent production of $\mathrm{PhD}$ coastal and ocean engineers appears to be relatively constant for the past seven years at just under one hundred per year. The challenge to regaining an international leadership role in this profession appears to declining federal government resources supporting the academic community and a paucity of government investment in modernization and maintenance of large scale experimental facilities. [10] was a 1984 attempt by those eminent in the profession at the time to bring this situation to national attention. Unfortunately, although well done, nothing tangible resulted from that effort. [11] (Meeting Research and Education Needs in Coastal Engineering) was another attempt in 2000 to revitalize coastal engineering research in the US by a study performed by the National Research Council with an eminent set of professors, practitioners and government agencies. This report met the same fate as it predecessor 16 years earlier. Reference 12 (What is the State of US Coastal Engineering and Science?) is the most recent known effort to focus on the priority of more national investment in coastal and ocean engineering research. Reference 12 was from a presentation by the President of the American Shore and Beach Preservation Association in 2011. This presentation was made to the U.S. Army Corps of Engineers Coastal Engineering Research Board.

\section{The Challenge and the Proposed Solution}

The authors view the challenge to be:

1. Diminishing coastal and ocean engineering leadership in the USA (a situation that has persisted for three to four decades)

2. Some consequences are

a. A threat to national security

-Naval ship experimental research accomplished overseas

(priorities dependent on foreign laboratories)

-Arctic ocean research leadership threatened

(with oceans warming arctic ice melting opens up a arctic for naval assets)

b. A threat to economic security

-coastal natural disaster costs need to be minimized through robust prevention, mitigation, response and recovery focused research -a backlog of maintenance/upgrading of beaches leads to diminishing income from international tourists. Research can help minimize maintenance costs -an acceleration of ocean/coastal farming research would decrease fish/shellfish imports and increase exports 
-research is necessary to better quantify sea level rise threats and mitigation strategies so long term cost effective responses can be developed -power production research from renewable ocean energy sources (tides/waves/biofuels) needs to be accelerated to lower cost

The authors believe the current state of affairs is the result of a number of complex phenomena and highly dispersed federal responsibility for coastal/ocean/marine engineering research. Coastal engineering research was relatively well centralized in the US Army Corps of Engineers until shortly after World War II. However as the Cold War raged and the economy thrived many agencies initiated research in coastal/ocean/marine engineering to satisfy their particular agency mission requirements. This research included Navy (several laboratories and ONR), NOAA, Coast Guard, National Park Service, National Science Foundation, and U.S. Geological Survey. These efforts proliferated and considerable funding was funneled to coastal/ocean/marine engineering related research. However, in the late sixties and early seventies time frame, the Vietnam War began to impact federal research resources. Then the Arab Oil Embargo led to some very high inflation years and federal agencies research budgets came under serious pressure. Research budgets did not keep pace with inflation and tended to be constant. This was especially true for research efforts that might be conducted in multiple agencies and facilities that were costly to maintain and operate. This situation plus a Navy decision to change the name of the world renowned David Taylor Model Basin (DTMB) to the Naval Ship Research and Development Center (NSRDC) ultimately led to the closing of large scale experimental DTMB/NSRDC facilities with a glorious history of ground breaking experimental investigations of ship resistance. This resulted in the U.S. Navy experimental ship research and development being performed at the Norwegian Hydraulic Laboratory in Trondbeim, Norway. The Corps of Engineers relocated its Coastal Engineering Research Center from Dale Carlia Reservoir to all new facilities at Ft. Belvoir, VA. However, the Vietnam War and Arab Oil Embargo led to several years of constant budgets and resulting high inflation in the late 1970's. This coupled with the manner in which new facilities were paid for in the Corps of Engineers put severe stress on the CERC budget resulting in substantially diminished funding for academic research. Additionally laboratory wave basin facilities were not completed at the Ft. Belvoir location. These events were catalysts for the Corps of Engineers decision to relocate CERC to the Waterways Experiment Station in Vicksburg, MS and merge ongoing coastal engineering research and development at WES with CERC. Although the relocation was highly successful, budgets for funding academic research fell far short of comparable buying power levels of the late 1950's early 1960's. During the past two decades the Corps of Engineers district offices have contracted more and more of their planning and design studies to the private sector. This trend has included contracting with foreign coastal and ocean engineering firms to detriment of the private sector US firms in this area. Sometimes design studies have been contracted to foreign laboratories. Furthermore the European Economic Union has mandated the oil companies and other corporations drilling in the North Sea and other areas perform any laboratory studies needed in European laboratories. This situation leads to US firms helping support foreign laboratories. Through the last three decades, continuous pressure on mission agency research budgets has severely eroded coastal, ocean and marine engineering research performed in the academic community. Budgets in government laboratories continue to diminish and capital investments in coastal/ocean engineering experimental facilities at government laboratories have been non-existent for well over a decade. 


\section{The Solution}

The authors propose another national study be performed to recommend a solution that would remediate, heal and revitalize the coastal, ocean and marine engineering research leadership in the USA. Specifically, we recommend that appropriate federal agencies commission the National Research Council (probably the Marine Board) to perform the study. Past national studies $[10,11]$ while well done, have not resulted in action. The study team needs to be well balanced with members from the private sector and academia. The government agency study liaisons would be well known and respected leaders as they were in the 1984 and 2000 studies. -The study could be funded by the five entities: Department of Defense (ERDC and Office of Naval Research), Department of Homeland Security (Office of University Programs), Department of Commerce (NOAA), Department of Interior (US Geological Survey), and National Science Foundation (Engineering Division) who are the four primary agencies with missions encompassing coastal, ocean and marine engineering research. Other agencies would be contacted if determined to participate.

Some suggested terms of reference to explore for the study include:

- Identify the major engineering research challenges that face the coastal, ocean and marine community during the next 50 years and the national import of solving (not solving) these challenges.

- Assess the productivity and stature of the US coastal, ocean and marine engineering profession.

- Assess the coastal, ocean and marine engineering degree productivity of U.S. Universities.

- Explore recommending innovative and practical mechanisms for the federal government to implement by legislation which would serve as a pilot for funding national priorities (coastal, ocean and marine engineering) that span the missions of several agencies.

- A two year time limit for completing the study.

\section{Acknowledgements}

The authors wish to acknowledge Jackson State University (JSU) and the Coastal Hazards Center of Excellence at JSU sponsored by the Department of Homeland Security for supporting this investigation. Mr. Thomas W. Richardson, Deputy Director, Coastal Hazards Center of Excellence, Jackson State University is gratefully acknowledged for many enlightening discussions and cogent comments that greatly enhanced the insights contained in this paper. The Engineer Research and Development Center of the US Army Corps of Engineers is acknowledged for making their comprehensive coastal engineering library available to the authors.

\section{REFERENCES}

[1] Wiegel, Robert L., “Oceanographical Engineering,” Prentice Hall, Inc. 1964

[2] Esturay and Coastline Hydrodynamics, Arthur T. Ippen, McGraw Hill Book Company, Inc. 1966

[3] Proceedings of the 30th International Conference on Coastal Engineering, San Diego, CA, 2006

[4] Proceedings of the 25th International Conference on Coastal Engineering, Orlando, FL, 1996 
[5] Proceedings of the 19th International Conference on Coastal Engineering, Houston, TX, 1984

[6] Proceedings of the 15th International Conference on Coastal Engineering, Honolulu, HA, 1976

[7] Proceedings of the 12th International Conference on Coastal Engineering, Washington, D.C., 1970

[8] Proceedings of the 5th International Conference on Coastal Engineering, Gainsville, FL, 1957

[9] American Society for Engineering Education Engineering Data Management System, http://edms.asee.org/.

[10] National Hazards and Research Needs in Coastal and Ocean Engineering, Summary and Recommendations to the National Science Foundation and the Office of Naval Research, Ad Hoc Committee for the Civil and

Environmental Engineering Division, National Science Foundation, Edited by John H. Nath and Robert G. Dean, November 1984

[11] Meeting Research and Education Needs in Coastal Engineering, Marine Board, Commission on Engineering and Technical Systems, National Research Council, National Academy Press, Washington, D.C., Copyright 2000. www.nap.edu/openbook.

[12] What is The State of U.S. Coastal Engineering and Science?, Harry Simmons, $88^{\text {th }}$ Proceeding of the Coastal Engineering Research Board Meeting, July 27, 2011, http://chl.erdc.usace.army.mil/cerb88 